\title{
Marcin Laberschek
}

ORCID: 0000-0000-6825-7695

Jagiellonian University

marcin.laberschek@uj.edu.pl

DOI: 10.35765/pk.2019.2603.010

\section{Barriers in Servicing Visitors \\ of Heritage Trails - the Example of Cultural Trials in Małopolska}

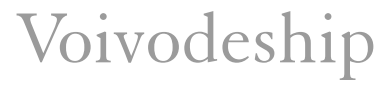

\section{AB STRAC T}

The popularity of cultural heritage trails is on the rise. The paper describes barriers which a person who wants to travel using cultural heritage trails of the Małopolska heritage/cultural trails may face. The author attempts at finding out whether cultural heritage trails operators are able to deal with their increasing popularity. To answer this question, a "mystery tourist" study was done. The tourist-researcher examined the quality and availability of needed information, both via an Internet platform and by making phone calls with trail operators. It has been shown that the barriers in servicing the "mystery tourist" were focused especially on two areas: establishing contact and telephone conversations with the operators of the trails and the inadequate functionality of the "Szlaki Małopolski" Internet platform. The paper describes detailed results of the research.

KEY WORDS: cultural trails, Małopolska heritage trails, mystery tourist, tourist service 


\section{STRESZCZENIE}

Bariery $w$ obstudze osób odwiedzajacych szlaki dziedzictwa na przyktadzie matopolskich szlaków kulturowych

Szlaki kulturowe to jedna z prężniej rozwijających się sfer działalności kulturalnej. Powstaje coraz więcej tego typu inicjatyw, w ślad za tym zwiększa się zainteresowanie osób chętnych do odwiedzenia miejsc o szczególnej wartości kulturowej. Powstaje więc pytanie, czy organizacje, które zarządzają szlakami kulturowymi, są w stanie sprostać zwiększającemu się zainteresowaniu? Czy hipotetyczny turysta, który wraz z rodziną planuje odwiedzić jeden ze szlaków i chciałby uzyskać niezbędne informacje, może liczyć na pomoc? By udzielić odpowiedzi na powyższe pytania, przeprowadzono badanie jakościowe metodą „tajemniczego turysty”. Wykazano, iż bariery w obsłudze „tajemniczego turysty" koncentrowały się zwłaszcza na dwóch obszarach: nawiązywania kontaktu i rozmów telefonicznych z operatorami szlaków oraz nienależytej funkcjonalności platformy internetowej „Szlaki Małopolski”.

\section{SŁOWA KLUCZE: szlaki kulturowe, szlaki Małopolski, operator szlaku, tajemniczy klient, tajemniczy turysta, obsługa turysty}

\section{Introduction}

It is not uncommon for us to be obliged to establish closer contact with various types of organizations, for example: tax office, grocery store, or dance school. The reasons for entering into such relationships may be varied, for example: obtaining a certificate of non-taxation, returning overdue goods, or obtaining information about available dance courses. In such and similar situations, an appropriate approach is expected from the organization, perhaps efficient and effective, but above all, one where the most important criterion will be to help the person who needs it at a given time. Therefore, it is worth noting that all activities in the area of customer service ${ }^{1}$ should

1 Through pejorative overtones, the phrase "customer service" may be questionable when used in humanistic management considerations. This is because it is characteristic of scientific studies that fall within the field of the functionalist paradigm of management sciences. In this work, however, it is used because it precisely defines the sphere of activity of the organization that has been explored, but there is no non-functional equivalent thereof. Besides, it is 
be based on the foundation of humanistic management, where the perspective, as Emil Orzechowski claims, of "caring for people" ${ }^{2}$ comes to the fore. In this paper, customer service will therefore be seen as a kind of care, namely the care provided by an organization to an outsider

There are situations where an "outsider" is deprived of care or an organization does not provide it in the way expected by the recipient. The aim of this article is to identify and analyze the kind of problems that are revealed in cultural activities, barriers to service provision to a tourist who plans to visit one of the cultural trails of Małopolska with his family. In connection with the future trip, he tries to search for relevant information on the Internet and tries to make a phone call to the relevant organizations who are operators of the trails. The paper will therefore show to what extent the tourist could count on the help of the relevant organizations and what problems arose on this occasion.

\section{Humanistic perspective on customer service}

From the formal point of view, customer service is a specific method of building and organizing the relationship with a recipient and the course of the relationship itself happening when they express (or may express) the need to contact the organization (in order to obtain information, express an opinion, place an order, etc.). It is worth noting that the implementation of customer service mechanisms is dictated not only by current but also potential actions taken by the recipients. Therefore, customer service should not just be a response, or a kind of reaction to the recipients' attempts to make contact. It should be ahead of their expectations, designed before the need arises. It also seems that the elements of service should be personalized. Customer service is an idea of the organization how to take care of a particular person who is expecting to be listened to, to get information, and to get help. Customer service "breaks the ice" between the organization and its "human" environment. of course, this is primarily a theory. The literature, including economic marketing literature, indicates and emphasizes what a "modern," humanist approach to customer service should look like. The role of customer relationship management

worth noting that "customer service" is seen here through humanistic prism as a kind of care for the person communicating with the organization. It should also be noted that in the following work the word "customer" has been replaced by a more subtle, but also more precise from the research point of view word "tourist."

2 E. Orzechowski, Arte et ratione, in: Zarzadzanie humanistyczne, eds. B. Nierenberg, R. Batko, Ł. Sułkowski, Wydawnictwo Uniwersytetu Jagiellońskiego, Kraków 2015, p. 71. 
is emphasized here, especially approaches such as individualized marketing and especially customer empowerment. ${ }^{3}$ However, reality may differ and in many cases doe differ from idealistic theoretical assumptions. The author of the present study has discovered one of such real cases, with regard to the problems encountered by tourists in contacting the operators of cultural trails.

It is worth noting that customer service does not only happen directly. This is because we deal with it not only when a representative of the organization establishes a direct relationship with us (face-to-face or by phone), but also indirectly when the organization provides convenient access to the information you may want to use (e.g. via a website, leaving the information in a visible place at the organization's headquarters or sending it to a recipient's address). The organization should also be guided by the sensitivity of the recipient, who for various reasons will not want to establish a direct relationship. The two presented ways of customer service can be called active (direct) and passive (indirect) service.

Orzechowski's humanistic message of "human concern" should be understood very broadly and one should be aware that the good of one person can cause discomfort to another. Some activities aimed at improving the level of customer service may put employees of the organization in a burdensome position and thus cause negative reactions. An example of this can be found in Arlie R. Hochschild's book The Managed Heart. Commercialization of human feeling, ${ }^{4}$ where the store personnel was instructed to attach a dollar bill to clothes where it could be seen, so that a dissatisfied customer could take it as compensation for inadequate service. Such actions are not consistent with the principles of humanistic management. In this context, there is a need to maintain an appropriate balance between the audience and the comfort of the people who contribute to the organization, as increasing emphasis on one of these aspects may be at the expense of the other.

\section{Customer service in culture}

All the above observations can be applied to organizations pursuing cultural activities. After all, customer service procedures are used by cinemas, theaters, operas, philharmonics, museums, cultural centers, theme parks

3 P. Kotler, K.L. Keller, Marketing, Poznań 2018, pp. 148-151.

4 A.R. Hochschild, Zarządzanie emocjami. Komercjalizacja ludzkich uczuć, Wydawnictwo Naukowe PWN, Warszawa 2009, pp. 156-157. 
and many others. In this respect, we can also talk about passive and active customer service. Let us take the example of a theater: the former can include the possibility of buying a ticket online, or having proper access to the theater's repertoire at its headquarters. An active example could be finding out about a performance over the phone direct communication with the ticket office at the theater. What is important is that in direct handling, attention should be paid not only to the course of the conversation itself, but also non-verbal elements may appear. This was pointed out by Łukasz Gaweł: “The way they behave [the staff - author's note], but also the way they look, how they present themselves, what attitude they take all this influences the overall assessment of the institution in the eyes of visitors," 5 and therefore stresses "that the staff of the organization become part of its image." ${ }^{6}$ Not surprisingly, the director of the Ethnographic Museum in Krakow in 2008, who pointed out that the staff dealing with visitor service should stop reading newspapers while performing their duties, recommended reading books instead. ${ }^{7}$ This treatment had primarily image significance: a person reading a book evokes different and deeper associations than a person reading a newspaper.

We can also talk about customer service (or rather a tourist, as discussed below) in relation to other cultural activities, namely cultural routes. In very general terms, the cultural trail is a designated route combining thematically selected objects of particular cultural importance. Experts insist on other aspects: "A cultural route is a thematic trail, having cultural value or an element of cultural heritage as its focal point, with a key role of cultural attractions." ${ }^{8}$ In one way or another, a cultural trail is a physically existing place that is accessible to those willing to visit it. However, the service for visitors to the trail should not only be provided on site, during the sightseeing, but also available for those who want to get information before arriving, as well as for those who have already visited the trail but are willing to additionally contact the representatives of the attraction. In each of these cases, there can be active and passive support provided.

5 Ł. Gaweł, Szlaki dziedzictwa kulturowego. Teoria i praktyka zarządzania, Wydawnictwo Uniwersytetu Jagiellońskiego, Kraków 2011, p. 169.

6 Ibidem, p. 169. More information on the impact of customer service on the image of an organization (not necessarily operating on the cultural market) can be found in the book: J. Barlow, P. Stewart, Markowa obstuga klientów. Nowe źródto przewagi nad konkurencja, Wolters Kluwer, Warszawa 2010.

7 Ł. Gawel, Szlaki dziedzictwa, op. cit., p. 169.

8 L. Puczkó, T. Rátz, Trailing Goethe, Humbert, and Ulysses. Cultural Routes in Tourism, in: Cultural Tourism, Global and Local Perspectives, ed. G. Richards, The Haworth Hospitality Press, New York 2007, p. 133. 
It is also worth noting that in relation to cultural routes it is difficult to talk about customer service. It is hard to call a tourist on a trail a customer. For the purposes of this article, therefore, I have introduced the term "tourist service." In a way, it is in conflict with the concept of Lukasz Gawel, who unambiguously separates tourist trails from cultural ones, ${ }^{9}$ giving the latter a humanistic dimension. ${ }^{10}$ It is difficult to precisely determine the person visiting a cultural trail.

\section{Research problem and methodology}

In order to identify and understand the problems that may be revealed in the relations between tourists and cultural trail operators (trail management organizations), the following research question was asked: what are the barriers to the service of a tourist who plans to visit selected facilities on the trail of interest to him/her together with his/her family? To provide an answer, the author of the work played the role of an "ordinary" tourist - an inhabitant of Pomeranian Voivodeship, a husband and father of two children, who tries to plan a weekend (Saturday-Sunday) trip for the whole family. In addition to creating a personal and social profile of the tourist, the author outlined the scenario of the actions he took, and then applied them in his research practice. Thus, first the tourist was to search the Internet for the information he was interested in and then try to contact the trail operator by phone to ask for details. Telephone contact is particularly important here because the cultural trails are often complex structures - both in terms of the length of the route and the number of facilities - while, according to the assumption, the tourist and his family had only two days at their disposal. Therefore, it was necessary to make an appropriate selection of objects, to visit those that can be considered representative for a given route - the tourist asked representatives of the route operator about appropriate recommendation of sites (and at the same time about other important issues). The study was conducted in the period between November 29 and December 14, 2016.

"Mystery tourist" is a method of research inspired by the classic "mystery shopping" method used in marketing research:

It can be successfully used to assess the quality of a tourist product or service, to examine the service provided by the tourist facility (attractions,

9 Ł. Gaweł, Szlaki dziedzictwa, op. cit., pp. 73-75.

10 Ibidem, p. 74. 
enterprise, hotel), its consistency with the assumptions of the facility, quality and compliance with the applicable internal standards. Mystery shopping allows you to assess, diagnose and optimize the quality of services in hotels, shops, restaurants and tourist attractions. ${ }^{11}$

However, the "mystery tourist" approach used in this study is different from the traditional-functional one. In classical terms, mystery shopping is a specific type of objectivized observation, ${ }^{12}$ where the person conducting the study is usually a "paid observer" ${ }^{13}$ who "plays the role of a client and observes the process of service." ${ }^{14}$ Meanwhile, the research described in this article also focuses on qualitative aspects (language of communication, emotions accompanying the communication, elements of personal culture), while the researcher remained in hiding and did not meet with the respondents face to face (the contact took the form of a telephone conversation - the telephone approach is found in mystery shopping research). ${ }^{15}$ Additionally, the passive side of the service was also studied the way of making the content available to the recipients on the Internet. Although both approaches relate to the quality of service processes, ${ }^{16}$ the traditional method is all about showing and exploring the internal problems of the organization in the context of preserving quality: "what makes it difficult for employees how they act in contact with customers and how they perform the tasks entrusted to them," ${ }^{17}$ while the perspective adopted in this work also emphasizes the personal experience of the outsider, a potential tourist, who is offered low quality assistance. Thus, to some extent, the research reveals the subjective position of the researcher-tourist.

11 Z. Kruczek, K. Cieszkowska, Możliwości zastosowania metody Mystery Shopping w ocenie jakości ustug turystycznych. Studium przypadku - termy w Biatce Tatrzańskiej, "Ekonomiczne Problemy Turystyki” 2(38) 2017, p. 49.

12 M. Rzemieniak, E. Tokarz, Mystery shopping w budowaniu tożsamości organizacyjnej, Politechnika Lubelska, Lublin 2011, p. 25.

13 G.A. Churchil, Badania marketingowe. Podstawy metodologiczne, Wydawnictwo Naukowe PWN, Warszawa 2002, p. 337.

14 E. Prymon-Ryś, Wykorzystanie metody mystery shopping $w$ badaniu jakości ustug finansowych, Prace Naukowe Akademii im. Jana Długosza w Częstochowie, Iss. V, Częstochowa 2011, p. 151.

15 A. Mazurkiewicz-Pizło, W. Pizło, Tajemniczy klient jako metoda badawcza - wybrane problemy, "Polityki Europejskie, Finanse i Marketing” 20(69)2018, p. 118; K. Kowalik, M. Mazur, Badanie jakości procesu obstugi klienta w kinie metodq "Tajemniczy klient," "Archiwum Wiedzy Inżynierskiej” Vol. 1, Iss. 1, 2016, pp. 53-55.

16 M. Meder, Zastosowanie metody Mystery Shopping w bankowości detalicznej, "Marketing i Rynek” No. 5/2005, p. 16.

17 E. Prymon-Ryś, Wykorzystanie metody, op. cit., p. 151. 


\section{Analysis of the "mystery tourist" experience. Stage I}

By entering "cultural trails" in the Google search engine, the tourist-researcher reached the "Szlaki Małopolski" platform established and run by Małopolska Institute of Culture (MIK), an important part of which is a database of Małopolska's cultural trails. It is worth mentioning that the tourist made such a choice, because the platform was positioned on the first place on the Google results list. Figure 1 presents a banner, which was placed on the main page of the website during the research period.

Figure 1. Banner at the main page of the Szlaki Małopolski website

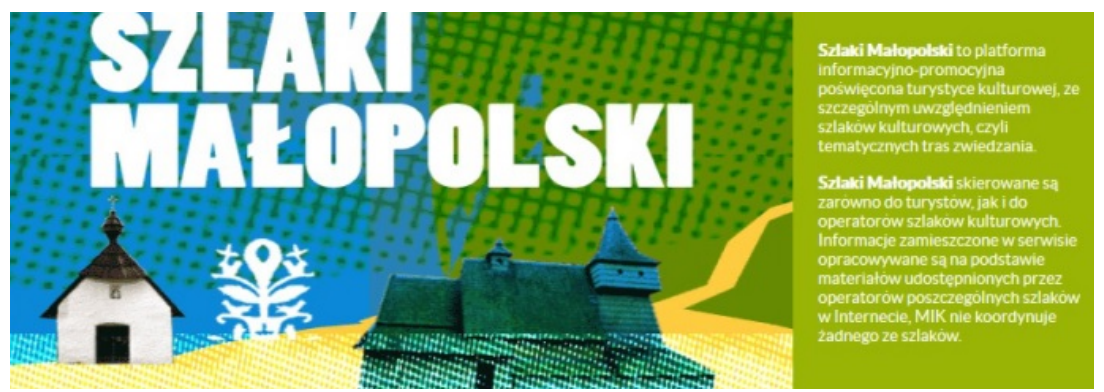

Source: http://szlakimalopolski.mik.krakow.pl/ (access: 12.01.2016).

From the information presented in the banner it can be concluded that the tourist "arrived at the right place." It is a website dedicated to "cultural tourism, with particular emphasis on cultural trails" and is addressed to tourists (although also operators). The role of the MIK is also indicated: it seems to focus exclusively on activities related to the operation of the platform itself, consisting in the inclusion of route information in its structure. The MIK, on the other hand, "does not coordinate any of the routes;" therefore, it appears that those interested will not receive any further information from the MIK about the routes themselves. This action is somehow "passed on" to the trail operators.

On the main page, just above the banner in question, there is a navigation bar. After clicking on the "trails" button, the researcher-tourist is moved to the subpage where the cultural trails database is located. Figure 2 shows a detail of the database. 
Figure 2. View of the database of cultural routes at Szlaki Małopolski

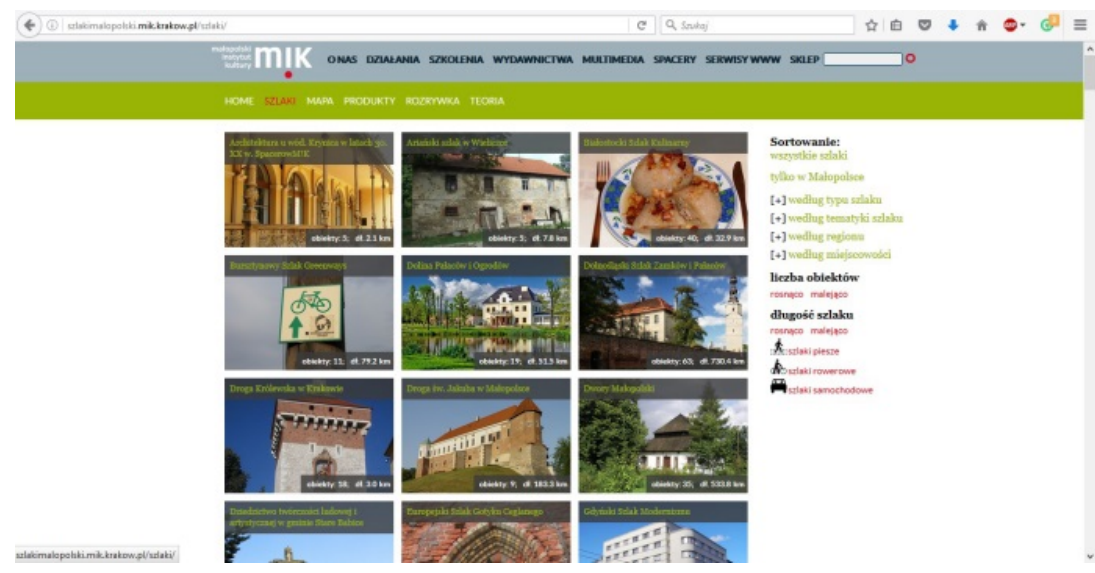

Source: http://szlakimalopolski.mik.krakow.pl/szlaki/ (access: 12.01.2016).

It should be stressed that the way of presenting the base of cultural trails is attractive for a potential tourist. The design emphasizes aesthetics and transparency. However, attention should be paid to the shortcomings of the platform user, which may be misleading. Some of the trails from the available collection, including 6 visible in illustration No. 2 (among others: The Bialystok Cultural Route, the Lower Silesian Route of Castles and Palaces, the Gdynia Modernism Route), are not cultural trails from the area of Lesser Poland, while the portal is called exactly that. This association may be misleading for those without sufficient geographical knowledge. The MIK, which manages the platform, has therefore made a mistake in the area of passive tourism. At the same time, it should be stressed that a possibility of "sorting" the trail base has been introduced. Right next to the set of images, on the right hand side, there is a list of different sorting options. After selecting the option "only in Małopolska" we receive a database of routes exclusively related to the Małopolska province. However, this does not change the fact that the name of the website is not appropriate to its content.

The "mystery tourist" took further action. After selecting the option "only in Małopolska," he received a filtered base of 96 trails located in the region in question, arranged in a manner analogous to Figure 2. Clicking on each position takes you to a subpage of a particular route. The tourist-researcher visited a subpage of each of the 96 trails. One of them (the Zamoyski Route in Zakopane) is shown in Figure 3. 
Figure 3. A subpage from the MIK platform presenting a selected cultural route in Małopolska

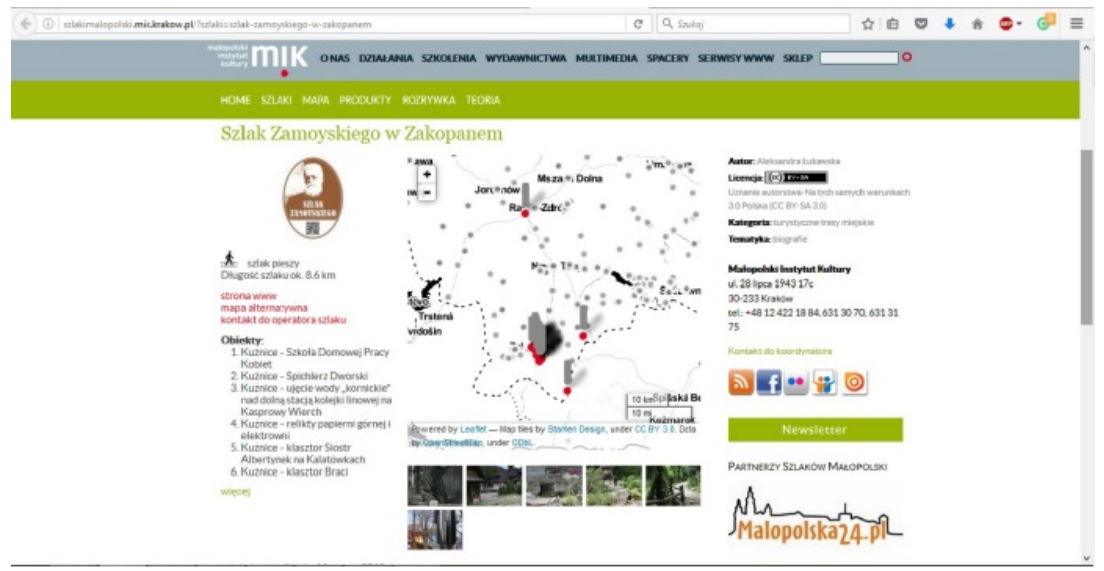

Source: http://szlakimalopolski.mik.krakow.pl/? szlaki=szlak-zamoyskiego-w-zakopanem (access: 12.01.2016).

On each subpage dedicated to a particular cultural route, there was a description of it (which was located in the area of the page invisible in Figure 3, below the map and the photograph), pictures, an interactive map, a list of objects and a set of links (located on the left side of the map, highlighted in red): "website," "alternative map," "contact operator trail." It is worth reminding at this point that the task of the "mystery tourist's" task was not only to obtain general information about the route, but also to contact the operator by phone to ask for details. Meanwhile, there are no direct telephone contacts on the route subpages, so the tourist chose to click on the last of these links. It moved the tourist to the place on the operator's website where the phone number was located. Visiting each of the 96 sub-routes, the tourist obtained the opportunity to transfer go to the website of each operator.

Attempts to carry out these 96 operations have resulted in several important observations. First of all, it turned out that in all cases one route did not exactly correspond to one operator. Some of the external pages were linked to several or more links, indicating that one operator managed several routes simultaneously. On this basis I identified 42 organizations taking care of trails dealt with under the MIK platform. For example, the Krakow Festival Office ${ }^{18}$ was responsible for 9 trails, the Krakow

18 It was not possible to determine the exact name of the operator in all cases (due to its absence on the site or due to the non-functionality of the site); in such cases, the domain to which the link from the MIK platform led was used instead of the name, e.g.: www.krakow.travel. 
City Hall for 7, the Historical Museum of the City of Krakow for 5 and the Tarnow Information Center for 3. It should be noted at this point that the operator of the largest number of routes turned out to be MIK (the same organization which is responsible for the Szlaki Małopolski platform). A total of 17 links led to the external website of the MIK, namely a place with visible contact details of the operator, including a telephone number. This makes it all the more puzzling that the MIK "does not coordinate any of the routes." Meanwhile, the link "contact to the trail operator" may encourage potential tourists to make direct contact with the MIK and obtain more information. The "mystery tourist" took advantage of the opportunity as is described later in the article.

For one of the routes, its operator has not been identified. On the subpage dedicated to the World War I Cemeteries Route there is no appropriate link. However, bearing in mind how a hypothetical tourist who wants to learn about the trail may behave, the "mysterious tourist" took an additional action: he entered the name of the trail in Google search engine. This operation also failed to deliver the expected result of accessing the website or obtaining a telephone number for the operator. ${ }^{19}$

However, the biggest problems at the level of passive tourist service appeared after clicking on the "contact to the trail operator" links. In some cases the "mystery tourist" was redirected to a place in the structure of the operator's website that did not exist (there was an error - as in the example shown in Figure 4) or the information was received that "the page with the given address does not exist" (as in the case of the Carpathian-Galician Oil Trail). A total of 13 such situations were recorded (per 42 providers). It is also worth noting that one of the redirections, to the external website of the Cistercian Trail in Poland, was blocked by the researcher's antivirus program (Figure 5).

19 It is worth sharing an observation at this point: the researcher's inquisitiveness could eventually lead to the acquisition of relevant data; however, I had to take into account, despite its intangible nature, the patience of a hypothetical tourist. 
Figure 4. Inactive page a trail operator website

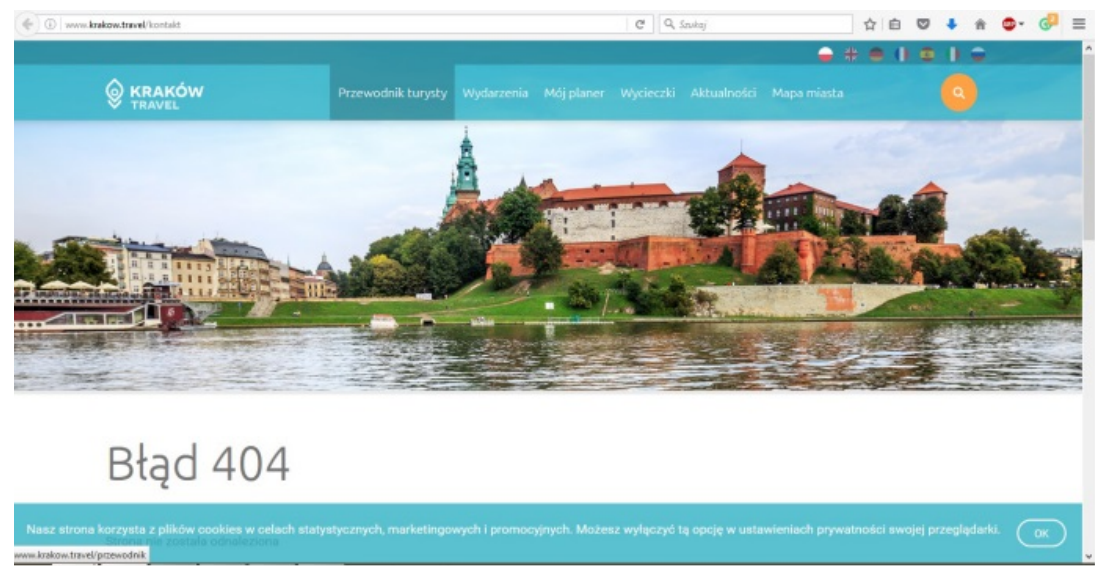

Source: http://www.krakow.travel/kontakt (access: 12.01.2016).

Figure 5. Page blocked by antivirus

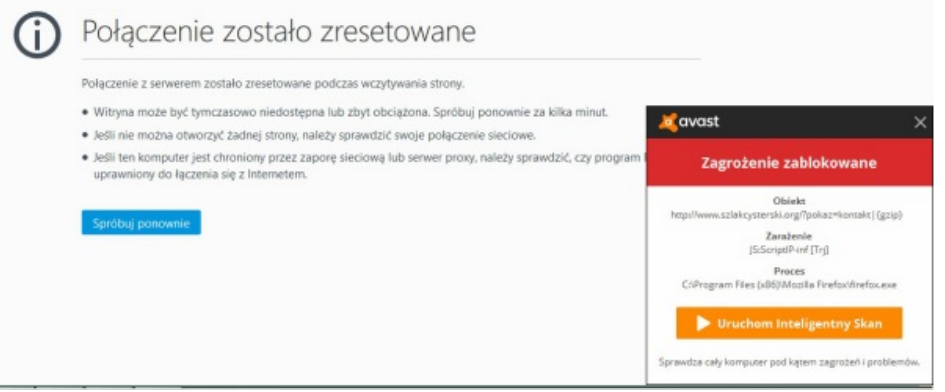

Source: http://www.szlakcysterski.org/?pokaz=strona_glowna (access: 12.01.2016).

It seems that the discussed examples of shortcomings identified by the "mystery tourist" are equally relevant to the MIK, which is responsible for providing tourists with a properly functioning database of trails and operators who should ensure that the trail site is properly linked to any external databases, especially those created on the basis of materials made available. The Szlaki Małopolski website contains a database of routes prepared in this manner (as indicated by the content contained in Figure 1).

It should be added that when the "mystery tourist" moved to the operator's website, which for various reasons was not working, he made additional 
attempts to access it. As mentioned earlier, he entered the trail name in Google search, or shortened the domain extension, leaving its basic form. The latter option was used, among others, in the case of the Karol Wojtyła Trail in Wadowice, when he was redirected from the MIK website to an inaccessible subpage at http://www.it.wadowice.pl/KONTAKT.35.0.html, when he removed the extension "/KONTAKT.35.0.html." This allowed him to reach the website of the trail operator, the Tourist Information in Wadowice - from where he obtained the telephone number.

Using redirection from the "Szlaki Małopolski" platform or by performing additional operations (as mentioned in the previous paragraph), the "mystery tourist" acquired telephone numbers of the operators of cultural routes, although it is worth stressing that ultimately this was not possible in every case. However, thanks to this, he performed the next stage of research, consisting of the establishment of direct relations with the operators and acquisition of necessary information.

\section{Analysis of the "mystery tourist" experience. Stage II}

When contacting the trail operators by phone, the "mystery tourist" prepared a list of questions that might occur during the conversations. The most important of them was the one that concerned the most valuable sites on the trail, those that could be particularly noteworthy. Let us remember that the short time of the planned trip did not allow the tourist and his family to visit the whole trail, so it became important to find out which elements on the route can be skipped. Another question concerned which of the sites is the most worthy of attention? How to get there? Does visiting involves any charges? Are there any visiting hours? Can one use the services of a guide? Is there someone on the sites to provide additional information about the trail? Are there guidebooks, leaflets, brochures or maps? Can you come with your children? Is there a restaurant or accommodation? of course, in various conversations, various questions were used. Their number and order was not obligatory. It was above all about the nature of the conversation, which should be easy, natural and not arousing suspicion in the person providing the information.

During telephone conversations, the "mystery tourist" encountered various problems. In two cases, he found out that the trail he was asking about does not exist, and to be precise, is not a trail in a literal sense. This was the case when he reached the "Sokół" Małopolska Cultural Center in Nowy Sącz, operator of the Małopolska Mansions route indicated by MIK. The man I spoke to provided the following information: 
We do not have a trail about mansions in Małopolska. First of all, we have a three-volume publication called Dwory Matopolski. Historia $i$ wspótczesność ... And secondly, we do have a website called Dwory Małopolski. But we surely do not have a mansions trail.

The "mystery tourist" explained that he got in touch through the Szlaki Małopolski website and that he would like to get specific information about the trail. The employee again, however, stated that the trail did not exist, or at least he did not have any information on this topic.

The second case was a bit different, and concerned the Krakow-Moravia-Vienna Greenways route. The operator indicated by Szlaki Małopolski turned out to be the tourist operator named Vitrivius Sp. z o. o. The person who answered the call from the tourist-researcher provided information that the initiative is not a cultural route. The Krakow-Moravia-Vienna Greenways is only a commercial offer for group cycling tours on request. After placing an order, a specific route for the trip is planned.

In the above situations we cannot talk about mistakes in the area of active tourist service. Those interviewed by the "mystery tourist" could not provide the information which he expected. However, defects appeared at the level of passive service, the manager of the Szlaki Małopolski website did not make sure that the information posted corresponded to reality.

It is worth noting that among the operators whose telephone numbers were obtained, only one was identified, however, I failed to make contact with it; it was NADwyraz foundation which manages the Małopolska Craft Trail. Four unsuccessful attempts to connect were made, each time selecting either a mobile number or landline. A telephone call was made to each of the other operators, but in 16 cases there were three types of complications: firstly, trying to make contact several times (because the subscriber had their phone switched off, was out of range or did not answer the call), secondly, dialing another phone number (where the "mystery tourist" was redirected to another, more topic-oriented person) and thirdly, having to make the phone call on another day (because the responsible person was not available).

One example, where a tourist was "redirected" twice to more competent people, concerns the Museum of Krakow and the cultural route titled Ghetto through the eyes of a child. Stella Müller-Madej. Using the telephone number available on the operator's website, the "mystery tourist" made contact with the headquarters. From there, he was directed to the Visitor Center, where he explained what he was looking for and started a conversation with one of the employees. An excerpt of what he heard: 
In general, we do not have such information on the website ... [Researcher sensed consternation in the woman's voice] Wait a minute ... [hears him consulting a colleague] And did you find it with the current date? Because it was 2013. Because this year, we don't have any information that something is being done ... The walk can be done ... but we do not have a prepared trail, we have no questing, brochures, because it was a few years ago ... Wait a moment! [After a while] I see that the Ghetto eyes of a child is available ... So here you would have to contact Apteka pod Orłem directly.

The "mystery tourist" asked for a phone number and contacted the competent branch of the Historical Museum of Krakow, where he acquired all the information. A slightly more complicated situation took place in the case of the Małopolska Tourist Information System based in Krakow, which, according to the indications of the Szlaki Małopolski platform, dealt with the service of the Małopolska Trail of the Order of the Holy Sepulcher. First, the tourist-researcher made four unsuccessful calls to the operator (either he could not make the call or he was directed to another uninformed person), after which he was finally instructed to contact another institution in another city, Miechów. There he eventually acquired accurate and comprehensive information. It should be noted that there were more such cases where the "mystery tourist" obtained relevant information from a representative of an organization other than the one referred to by the link from the MIK platform. Despite significant barriers in active tourist service, it is worth noting that in 16 out of 33 cases no complications happened when trying to make telephone contact with the route operator.

However, barriers to active tourist service are not only difficulty in establishing a telephone relationship with the route operator. Even the most effective telephone connection does not guarantee that the tourist will receive what he or she expects to obtain the information he or she is interested in. Out of all 32 interviews with people who were indicated as competent, reached by the "mystery tourist," the relevant information was obtained from 26 (although in 6 cases the information was only partial, while in 20 cases it was as detailed as the tourist expected). Six conversations did not produce the expected results. This was the case, among others, with the Małopolska Institute of Culture, the operator of the largest number of trails (17), where the "mystery tourist" expected to be able to get more information in connection with the Dębina Architecture Route SpacerowMiK. The person who answered the call gave a concise statement: "We do not deal with the issue of organization." The situation was slightly different with the operator called Kraków Travel (an initiative coordinated by the Krakow Festival Office), to whose website 7 links from 
the MIK platform were directed. Here is a fragment of the obtained information about the sites which were recommended to the "mystery tourist" as the most interesting for the Krakow Fortress Route:

[Audible sigh] ... well, firstly, from the Krakow Fortress there is the Barbican, two, the historical route, which the Historical Museum organizes ... Only problem is that in the autumn-winter period they are closed.

It is not entirely clear for what reason, but it still seems that the lady provided misleading information to the "mystery tourist." The Barbican is not a site belonging to the Krakow Fortress Trail; which is formed by military objects of the nineteenth and twentieth century. Another situation was encountered by the tourist-researcher in the Nowy Sącz municipal office. The man who was selected as a competent person for the Intercultural Tourist Route of the Polish-Slovakian Borderland, did not provide the information for an unknown reasons, despite two requests from the "mystery tourist." He would send solely refer him to the trail guide.

It is worth emphasizing here, however, that in most cases, if there a conversation with the right person representing the trail did take place, the tourist-researcher obtained relevant information. However, the frequent need to make many calls, the necessity to contact many people and organizations can act as a deterrent to the "real tourist" and put the trail operator in a bad light.

At the end of this section it is worth paying attention to another important issue. During a conversation with a representative of the trail operator, the "mystery tourist" asked whether it is possible to obtain (receive or purchase) additional information materials about the trail - guides, guides, maps, etc. - whether in traditional (printed) or modern (electronic) form. In the vast majority ( 25 cases), the answer was yes, in the remaining 7 there was no such a possibility. It seems that this (passive) form of tourist service is the most emphasized one, so the inconveniences that a "real tourist" may experience in this field may be relatively minor.

\section{Analysis of the "mystery tourist" experience. Stage III}

After completing the study with the "mystery tourist" method, I summed up the course of the whole process by entering the results in Table 1. In the first column, trail operators are listed. In some cases, their names are given, while in other, where there was less possibility to acquire them (due to varying degrees of non-functional websites), the operator's domain 
name was used (e.g. www.regioraport.pl). In the next column there is the number of trails assigned to a particular operator. A total of 93 routes are contained in the column. It is worth recalling that when visiting the Szlaki Małopolski platform, a tourist-researcher identified 96 trails, however, with regard to one of them he did not determine the organization managing it, while in two other cases the trails turned out not to be trails in the strict sense. The column "website functionality" applied to the "mystery tourist" making attempts to go from the Szlaki Małopolski website to an operator's site. Properly functioning redirection was included in the sub-column "functional," while irregularities are noted in the sub-column "out of order." The next two columns refer to active service - on the telephone. The first of them refers to the effectiveness of the call. The sub-column "ineffective" refers to the situation of a contact failure. In turn, "effective" implies successful communication on the phone. If the contact took place without any complications this "effectiveness" was treated as "direct," while in other cases as "indirect." The second main column refers to the form of acquired information. If the "mystery tourist" received the expected information, then the appropriate check box is marked in the sub-column as "detailed", in cases of indirect information acquisition, as "partial," while in the as "none." The next column is "informational materials." In the case of the availability of such materials (folders, brochures, maps, guides, applications, etc.) in any form, it is indicated as "yes," or "no" in the case of a lack thereof. In the last column the operators are assigned points for "tourist service." For website functionality, 1 point was awarded, while a malfunction resulted in 0 points. Direct telephone communication provided 2 points, indirect - 1, and lack of communication -0 . Further, detailed information awarded 2 points, partial -1 , and none -0 . Finally, available information materials gave on 1 point, and no materials -0 .

Up to 6 points could be awarded, while the minimum possible result was 0 . The average of all ratings given to operators was 3.5 , which is a relatively low rating. Out of 42 operators, 10 received maximum points. 17 operators received ratings in the range of 5-6 points, where 5 points meant that diagnosed deficiencies related to the functionality of the operator's website or inconvenience while establishing a telephone contact. 11 organizations received between 0 and 2 points. This means basically that one out of four operators was not properly prepared to handle a potential tourist who is interested in visiting a cultural trail, or even completely unprepared. 


\begin{tabular}{|c|c|c|c|}
\hline \multirow[b]{2}{*}{ name of the operator, } & \multirow{2}{*}{$\begin{array}{c}\text { number } \\
\text { of } \\
\text { routes }\end{array}$} & \multicolumn{2}{|c|}{ functionality of the operator's site } \\
\hline & & functional & malfunctioning \\
\hline Małopolski Instytut Kultury & 17 & 市 & \\
\hline www.regioraport.pl & 1 & & 嫁 \\
\hline Kraków Travel & 7 & & 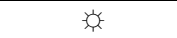 \\
\hline Bractwo św. Jakuba w Więcławicach Starych & 1 & 安 & \\
\hline Historical Museum of the City of Krakow & 5 & 涼 & \\
\hline CKSiT w Kalwarii Zebrzydowskiej & 1 & 安 & \\
\hline Urząd Gminy Gorlice & 1 & & 串 \\
\hline szlakmodernizmu.pl & 1 & $+\phi$ & \\
\hline www.Małopolskaromanska.pl & 1 & & 姲 \\
\hline Małopolska Tourist Organization & 3 & 家 & \\
\hline Sądecka Organizacja Turystyczna & 3 & 安 & \\
\hline Małopolski System Informacji Turystycznej & 2 & 市 & \\
\hline Gorczańska Organizacja Turystyczna & 2 & 凉 & \\
\hline Starostwo Powiatowe w Nowym Sączu & 1 & 家 & \\
\hline Urząd Gminy Poronin & 1 & 凉 & \\
\hline Urząd Miasta Krakowa & 7 & 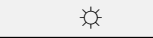 & \\
\hline Krakow Festival Office & 9 & 唯 & \\
\hline poland.pl/malopolskie & 1 & & 妏 \\
\hline Stowarzyszenie „Na śliwkowym szlaku” & 1 & 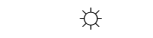 & \\
\hline Urząd Miasta Nowego Sącza & 2 & $\not<$ & \\
\hline Urząd Miasta Krynica Zdrój & 1 & 家 & \\
\hline www.szlakcysterski.org & 1 & & 凉 \\
\hline Starostwo Powiatowe w Zakopanem & 1 & 必 & \\
\hline Polskie Towarzystwo Turystyczno-Krajoznawcze Tarnów & 2 & $+\infty$ & \\
\hline Tarnowskie Centrum Informacji & 3 & 市 & \\
\hline Tourist Information in Wadowice & 1 & & 洝 \\
\hline Fundacja Miejski Park i Ogród Zoologiczny & 1 & & 凉 \\
\hline Muzeum w Bochni & 2 & $-\dot{\alpha}$ & \\
\hline Związek Gmin Jurajskich & 1 & 家 & \\
\hline Tatrzańska Agencja Rozwoju, Promocji i Turystyki & 1 & $+\infty$ & \\
\hline Fundacja NADwyraz & 1 & 家 & \\
\hline www.szlakstyluzakopianskiego.pl & 1 & & 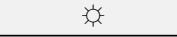 \\
\hline zszbiecz.pl & 1 & & 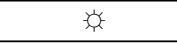 \\
\hline Klub im. Stanisława Zamoyskiego & 1 & & 姲 \\
\hline Zbójnicki Szlak & 1 & 家 & \\
\hline Municipal Cultural Center Nowy Targ & 1 & 家 & \\
\hline www.szlak-lubomirskich.stalowawola.pl & 1 & 必 & \\
\hline Punkt Informacji Turystycznej Wieliczka & 1 & 家 & \\
\hline regiaraport.pl & 1 & 姲 & \\
\hline www.szlakbursztynowy.pl & 1 & & 家 \\
\hline muzea.stary.sacz.pl & 1 & & 市 \\
\hline Stowarzyszenie „Gniazdo-Ziemia Proszowicka” & 1 & 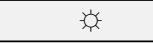 & \\
\hline
\end{tabular}


Marcin Laberschek - Barriers in Servicing Visitors of Heritage Trails

\begin{tabular}{|c|c|c|c|c|c|c|c|c|}
\hline \multicolumn{3}{|c|}{ phone support } & \multicolumn{3}{|c|}{ collected information } & \multicolumn{2}{|c|}{ informational materials } & \multirow{3}{*}{$\begin{array}{l}\text { number } \\
\text { of points }\end{array}$} \\
\hline \multicolumn{2}{|c|}{ effective } & \multirow{2}{*}{ ineffective } & \multirow{2}{*}{ detailed } & \multirow{2}{*}{ partial } & \multirow{2}{*}{ none } & \multirow{2}{*}{ yes } & \multirow{2}{*}{ no } & \\
\hline direct & indirect & & & & & & & \\
\hline \multirow[t]{5}{*}{ 淁 } & & & & & 如 & & 好 & 3 \\
\hline & & & & & & & & 0 \\
\hline & 媇 & & & 㛙 & & 琼 & & 3 \\
\hline & 媇 & & & & 凉 & & 凉 & 2 \\
\hline & 涼 & & 涼 & & & 婃 & & 5 \\
\hline \multirow[t]{2}{*}{ 家 } & & & 媇 & & & 婄 & & 6 \\
\hline & 媇 & & 嫁 & & & & 婄 & 3 \\
\hline \multirow[t]{2}{*}{ 家 } & & & 如 & & & 姲 & & 6 \\
\hline & & & & & & & & 0 \\
\hline 家 & & & & & 语 & & 宗 & 3 \\
\hline \multirow[t]{2}{*}{ 宗 } & & & 涼 & & & 济 & & 6 \\
\hline & 串 & & 唯 & & & 唯 & & 5 \\
\hline 唯 & & & 济 & & & 济 & & 6 \\
\hline \multirow[t]{5}{*}{ 安 } & & & & & 婄 & 宗 & & 4 \\
\hline & 媇 & & 凉 & & & 媇 & & 5 \\
\hline & 媇 & & & & 媇 & 婃 & & 3 \\
\hline & 媇 & & & 济 & & & 婄 & 3 \\
\hline & & & & & & & & 0 \\
\hline \multirow[t]{6}{*}{ 家 } & & & 如 & & & 济 & & 6 \\
\hline & 媇 & & 如 & & & 婃 & & 5 \\
\hline & 泫 & & 如 & & & 泫 & & 5 \\
\hline & & & & & & & & 0 \\
\hline & 好 & & 媇 & & & 嘌 & & 5 \\
\hline & 家 & & & & 婄 & 婃 & & 3 \\
\hline \multirow[t]{3}{*}{ 唯 } & & & 涼 & & & 泫 & & 6 \\
\hline & 安 & & 如 & & & 媇 & & 4 \\
\hline & 好 & & 涼 & & & 泫 & & 4 \\
\hline 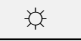 & & & & 定 & & & 家 & 4 \\
\hline 安 & & & 涼 & & & 济 & & 6 \\
\hline \multirow[t]{5}{*}{ 京 } & & & 如 & & & 婄 & & 6 \\
\hline & & 婄 & & & & & & 1 \\
\hline & & & & & & & & 0 \\
\hline & 涼 & & & 婄 & & 㴒 & & 3 \\
\hline & & & & & & & & 0 \\
\hline \multirow[t]{3}{*}{ 家 } & & & 如 & & & 涪 & & 6 \\
\hline & 济 & & & - & & 嫁 & & 4 \\
\hline & & & & & & & & 1 \\
\hline 婄 & & & & 婄 & & 㴒 & & 5 \\
\hline \multirow[t]{3}{*}{ 济 } & & & 许 & & & & 涼 & 5 \\
\hline & & & & & & & & 0 \\
\hline & & & & & & & & 0 \\
\hline$\not \dot{x}$ & & & $\not x$ & & & $\not x$ & & 6 \\
\hline
\end{tabular}




\section{Conclusion}

Thanks to the survey of organizations that manage Małopolska's cultural routes, on the one hand creating an Internet base, and on the other hand taking care of them, a number of problems came to light that might not have occurred if the survey had been based on quantitative methods. The qualitative research using the "mystery tourist" method revealed many hidden shortcomings. It turned out that if such a "real" tourist, who plans to go to Małopolska and therefore expects to be given more information, would have particular problems with making an efficient telephone conversation with the organization taking care of the route. These defects were especially focused on: the impossibility of making first contact, repeated "redirecting" of the conversation and the unavailability of a responsible person.

The second plane of disadvantages were non-functional technological solutions. In an age of widespread use of advanced technologies, a responsible organization should not allow something that is designed also to serve tourists be malfunctioning. One may not introduce modern solutions, but once one does have one, it should be useful.

However, it should be stressed that any solution, whether relating to the efficiency of telephone calls or the usefulness of new technologies, should be based on an elementary premise: that at any time, any person can "knock on the door" of the organization and ask for help. The organization should make every effort to meet their expectations. Route operators should also be guided by this premise. Any problems may adversely affect the image of the trail itself, which in the long run may result in a decrease in tourist traffic in the region. of course, even the most thorough preparation is no guarantee of success, but it reduces the risk of unexpected circumstances.

\section{BIBLIOGRAPHY}

Barlow J., Stewart P., Markowa obstuga klientów. Nowe źródto przewagi nad konkurencja, Wolters Kluwer, Warszawa 2010.

Chen R., Clayton J.C., Barrows W., Developing a Mystery Shopping Measure to Operate a Sustainable Restaurant Business: The Power of Integrating with Corporate Executive Members' Feedback, "Sustainability" 2015, 7, pp. 12279-12294.

Churchil G.A., Badania marketingowe. Podstawy metodologiczne, Wydawnictwo Naukowe PWN, Warszawa 2002.

Dziadkowiec J.M., Mystery Shopping - metoda oceny $i$ doskonalenia jakości ustug, "Problemy Jakości" 2004/10, pp. 24-27. 
Dziadkowiec J.M., Wybrane metody badania i oceny jakości ustug, "Zeszyty Naukowe Akademii Ekonomicznej w Krakowie” 717/2006, pp. 23-35.

Gaweł Ł., Szlaki dziedzictwa kulturowego. Teoria $i$ praktyka zarzadzania, Wydawnictwo Uniwersytetu Jagiellońskiego, Kraków 2011.

Hochschild A.R., Zarzadzanie emocjami. Komercjalizacja ludzkich uczuć, Wydawnictwo Naukowe PWN, Warszawa 2009.

Kotler P., Keller K.L., Marketing, Rebis, Poznań 2018.

Kowalik K., Mazur M., Badanie jakości procesu obstugi klienta w kinie metoda “Tajemniczy klient”, “Archiwum Wiedzy Inżynierskiej,” Vol. 1, Iss. 1, 2016, pp. 53-55.

Kruczek Z., Cieszkowska K., Możliwości zastosowania metody Mystery Shopping $w$ ocenie jakości ustug turystycznych. Studium przypadku - termy w Biatce Tatrzańskiej, "Ekonomiczne Problemy Turystyki," 2(38) 2017, pp. 47-60.

Mazurkiewicz-Pizło A., Pizło W., Tajemniczy klient jako metoda badaw$c z a$ - wybrane problemy, "Polityki Europejskie, Finanse i Marketing" 20(69)2018, pp. 112-126.

Meder M., Zastosowanie metody Mystery Shopping $w$ bankowości detalicznej, "Marketing i Rynek" 5/2005, pp. 14-20.

Orzechowski E., Arte et ratione, in: Zarzadzanie humanistyczne, eds. B. Nierenberg, R. Batko, Ł. Sułkowski, Wydawnictwo Uniwersytetu Jagiellońskiego, Kraków 2015, pp. 63-74.

Prymon-Ryś E., Wykorzystanie metody mystery shopping w badaniu jakości ustug finansowych, "Prace Naukowe Akademii im. Jana Długosza w Częstochowie” V, 2011, pp. 147-158.

Puczkó L., Rátz T., Trailing Goethe, Humbert, and Ulysses. Cultural Routes in Tourism, in: Cultural Tourism, Global and Local Perspectives, ed. G. Richards, The Haworth Hospitality Press, New York 2007, pp. 131-148.

Rzemieniak M., Tokarz E., Mystery shopping $w$ budowaniu tożsamości organizacyjnej, Politechnika Lubelska, Lublin 2011.

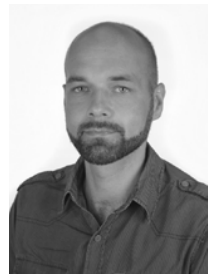

Marcin Laberschek - Ph.D. in Management Science; employee of the Department of Management, Economics of Media and Advertising at the Cultural Institute of the Jagiellonian University. Author of scientific papers on management and marketing in culture, media and advertising, including monograph: Symboliczne stanowienie wtadzy w organizacjach (2018). Since 2018, deputy editor-in-chief of the "Zarządzanie w Kulturze" scientific journal. His interests focus on research methodology in humanistic management, managing cultural organizations, symbolic and cultural dimensions of management, marketing and advertising, critical marketing, postmarketing and postmodern market management. 
